\title{
TRADITIONAL TREATMENT OF UNCOMPLICATED CASES OF FALCIPARUM MALARIA WITH PIPER BETLE (TRADITIONAL MEDICATION), AS OPPOSED TO TREATMENT WITH CHLOROQUINE
}

\author{
${ }^{1}$ Lilian Andries \\ ${ }^{2}$ Sunny Wangko \\ ${ }^{1}$ Benedictus S. Lampus
}

\begin{abstract}
${ }^{1}$ Department of Community Medicine, Faculty of Medicine, University of Sam Ratulangi Manado
${ }^{2}$ Department of Anatomy-Histology, Faculty of Medicine, University of Sam Ratulangi Manado

Email: lilianandries@yahoo.co.id
\end{abstract}

\begin{abstract}
Abstrak: Di Indonesia, penyakit malaria masih merupakan masalah kesehatan, malahan pada akhir tahun 2004 dan awal tahun 2005 terjadi KLB (Kejadian Luar Biasa) dengan beberapa kematian di beberapa daerah di Indonesia, termasuk Propinsi Sulawesi Utara. Terdapat berbagai kendala dalam penggunaan obat malaria seperti resistensi parasit malaria, obat baru yang mahal, serta belum tersedianya vaksin yang sesuai. Pengobatan dengan ramuan sirih (Piper betle, Linn.), daun mayana (Coleus Arthopurpureus), kuning telur, madu, dan wiski lokal "cap tikus" telah digunakan secara turun temurun olpengobatan tradisional, eh pengobat tradisional asal Propinsi Sulawesi Utara. Dilakukan Active Case Detection (ACD) dan uji efektifitas mengikuti kajian uji klinik. Efektifitas ramuan sirih dibandingkan dengan klorokuin dalam menghilangkan parasit malaria darah tepi. Analisis dilakukan terhadap 70 kasus yang positif parasit malaria falsiparum berusia 10-60 tahun dimana 35 kasus diberi perlakuan dengan ramuan sirih dan 35 kasus lainnya obat klorokuin (dosis standar WHO). Hasil ACD didapatkan prevalensi sebesar $8 \%(0-23,4 \%)$ pada 22 kelurahan. Ramuan ini efektif menghilangkan parasit malaria sebesar $91,4 \%$ pada akhir minggu pertama, sedangkan klorokuin 88,6\%. Pada akhir minggu ke-4 didapatkan 3 kasus yang diberikan klorokuin masih tetap positif terhadap parasit malaria, sedangkan dengan ramuan sirih semuanya negatif. Analisis dengan tes logrank (Kaplan-Meier) tidak menunjukkan perbedaan bermakna.
\end{abstract}

Kata kunci: obat tradisional, piper betle, klorokuin, parasit malaria

\begin{abstract}
Malaria is still a health problem in Indonesia. Even at the end of 2004 and the beginning of 2005, outbreaks took place in some areas of Indonesia, including the province of North Sulawesi. There are several obstacles to the use of malaria drugs including resistance of the parasite, unaffordable new drugs, and no available vaccines. Traditional malaria treatment which was a mixture of piper betle (Piper betle, Linn.), mayana leaves (Coleus arthopurpure$u s$ ), egg yolk, honey, and local whiskey "cap tikus" has been used for generations by traditional healers in North Sulawesi. The study was designed to ascertain the efficacy of the traditional treatment compared to that of chloroquine to eliminate parasitemia. Seventy cases of uncomplicated falciparum malaria found through active case detection were given either the traditional treatment or chloroquine. The traditional treatment was effective in $91.4 \%$ of cases, compared to $88.6 \%$ in the cases of chloroquine, in eliminating parasitemia by the end of the first week. By the end of the fourth week, all cases given the traditional treatment were negative of para-sitemia, while three cases given chloroquine were still positive. Analysis using the logrank test (Kaplan-Meier) showed no significant difference between piper betle extract and chloroquine.
\end{abstract}

Keywords: traditional medicine, piper betle, chloroquine, malaria parasite 
Since the era of Hippocrates malaria has been an endemic and dangerous disease in many countries, including Indonesia ${ }^{1}$. This disease is known as one of the major worldwide killers, especially in develop-ing countries. It is estimated that malaria kills one million people every year. ${ }^{2}$ The prevalence of its increase during 2004 2005 had been marked by extraordinary events in several areas of Indonesia, including the province of North Sulawesi.

Efforts to prevent and treat malaria have not been completely successful, particularly due to the lack of malaria vaccine (malaria vaccine is still on trial due to the fast mutation of parasites), ${ }^{3}$ and the resistance of malaria parasites to the available anti-malarial drugs, either old or new. In addition, the new generation of anti-malarial drugs eg mefloquine, ${ }^{4}$ artemisinin, ${ }^{5}$ and halofantrine, ${ }^{6}$ is expensive and hard to find while individual or national economic problems increase the death cases annually.

Since the prices of the new antimalarial drugs are relatively high for most people, traditional medicines have been investigated in an effort to find some new medical raw materials that are inexpensive and safe in the framework of supporting government programs for the prevention and ultimately the eradication of malaria.

In Indonesia since 1996, Plasmodia falciparum, that have become resistant to chloroquine in differing degrees, were found in 27 provinces. Resistance of $P$. falciparum to sulfadoxin-pyrimethamin (Fansidar) in-vivo and in-vitro has been reported in 11 provinces, including Sulawesi and Irian Jaya. The much worse $P$. vivax's resistance to chloroquine is found in Nias, Maluku, and Flores. ${ }^{7}$

Some studies have found out that piper betle had anti malarial potency. ${ }^{8,9}$ Research findings on piper betle, i.e. toxi-city tests and liver function tests were as follows: 1) The toxicity test of piper betle-ethanol extract determined LD $501768 \mathrm{mg} / \mathrm{kg}$ body weight (range $1453-2150 \mathrm{mg} / \mathrm{kg}$ body weight) for the Wistar rat, and $2900 \mathrm{mg} / \mathrm{kg}$ body weight (range 1166-4634 mg/kg body weight) for the Mus musculus Swiss strain,
2)The histopathological test of both the Wistar and Mus musculus groups showed that piper betle was a relatively safe test material (Examined by the Animal Laboratory in Bogor and investigated by the late Dr. Iwan Budiarso), 3) The Ex-vivo (liver perfusion) effectivity-test findings in the Wistar mice infected by $P$. berghei in a 7day observation did not show either liver enzyme alteration (SGOT and SGPT) or liver cell damage; moreover, microscopic investigation did not show any blue colour substances (trypan blue). ${ }^{10}$

Traditional healers from North Sulawesi (Bolaang Mongondow Regency) have been using piper betle nuts, mixed with mayana leaves (Coleus arthopurpureus), honey, egg yolk (from local hens), and "cap tikus" (a locally distilled traditional whiskey), to prevent and to treat malaria (Figure 1). This mixture provided by the traditional healers has been used by families for generations. In the past, women used to chew piper betle nuts; this habit for women was comparative to the smoking habit of men. Although chewing piper betle nuts is not popular anymore, this piper betle might be beneficial in handling malaria nationally due to its low cost and ease of acquisition. Mayana leaves are consumed by people in Mid Sulawesi province as daily vegetable.

\section{The objectives of the study}

In this paper, we compare the effect of piper betle used in a traditional medicine on eradicating plasmodia falciparum in cases of tropical malaria with that of chloroquine.

\section{METHODS}

The research was done in 2 stages. In the first stage (a descriptive survey design), the identification of active cases was carried out to pin-point uncomplicated malaria cases by means of: examining the malaria infected blood of the population under study in the endemic areas to identify $P$. falciparum. Then cases with positive $P$. falciparum were then subjected to physical and laboratory examinations (liver function test GOT and GPT 0-35 U/L, and renal 
function test serum creatinine $<1.5 \mathrm{mg} / \mathrm{dL}$ and uric acid $1.5-8.0 \mathrm{mg} / \mathrm{dL})^{11}$ to verify that they were pure uncomplicated tropical malaria cases. The second stage (a clinical test study) was for testing the effectiveness of piper betle on uncomplicated tropical malaria cases through an observation following clinically designed tests (without randomization). All of the laboratory examinations were done in the laboratory of Prof Dr RD Kandou Hospital Manado. Samples of uncomplicated tropical malaria cases were divided into two groups. Group 1 was treated with the mixture containing piper betle, and the other group with chloroquine (using the WHO standard dose). Beforehand, all the selected cases had to sign a consent form. This study was carried out with the approval by the Ethics Committees at The Faculty of Medicine, University of Sam Ratulangi, Manado, North Sulawesi province, Indonesia.

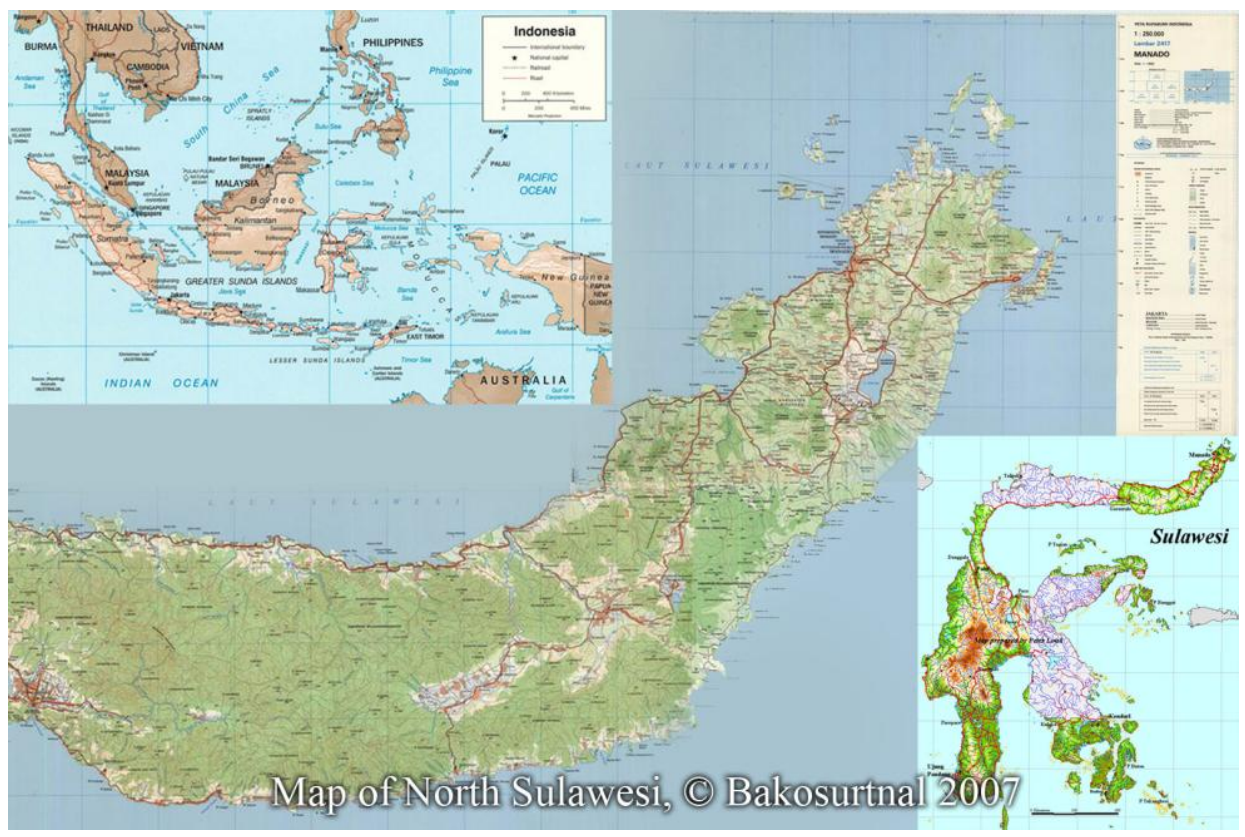

Figure 1. Map of Indonesian Islands, Sulawesi Island and North Sulawesi Province

Table 1. Design of descriptive and analytic study activities

\begin{tabular}{|c|c|c|c|c|c|c|c|c|c|c|}
\hline \multirow{2}{*}{ No } & & \multicolumn{9}{|c|}{ Day } \\
\hline & & 1 & 2 & 3 & 4 & 5 & 12 & 19 & 26 & 33 \\
\hline 1 & Thick blood test (ACD) ${ }^{1}$ & X & & & & & & & & \\
\hline 2 & Blood sample (Uncomplicated) & & $\mathrm{X}$ & & & & & & & \\
\hline 3 & $1^{\text {st }}$ day treatment & & & X & & & & & & \\
\hline 4 & $2^{\text {nd }}$ day treatment & & & & $X$ & & & & & \\
\hline 5 & $3^{\text {rd }}$ day treatment & & & & & X & & & & \\
\hline 6 & $1^{\text {st }}$ thick blood test after treatment & & & & & & $\mathrm{X}$ & & & \\
\hline 7 & $2^{\text {nd }}$ thick blood test after treatment & & & & & & & $\mathrm{X}$ & & \\
\hline 8 & $3^{\text {rd }}$ thick blood test after treatment & & & & & & & & $X$ & \\
\hline 9 & $4^{\text {th }}$ thick blood test after treatment & & & & & & & & & X \\
\hline
\end{tabular}


The design of descriptive and analytic study activities was as follows: thick blood test by ACD (day-1), collecting blood samples of uncomplicated tropical malaria (day-2), 3-consecutive-day treatment (day3,4 , and 5), and 4-consecutive-week-thickblood test after treatment (day-12, 19, 26, and 33).

\section{Population}

In this research the population was taken by Active Case Detection (ACD) from several malaria endemic areas in North Minahasa Regency, Manado City, South Minahasa Regency, and Minahasa Regency.

\section{The inclusive and exclusive criteria of the samples}

The inclusive criteria were as follows: approval of informed consent, age $10-60$ years with positive blood test for $P$. falciparum, genders (men and women), and uncomplicated cases, based on the liver function and kidney function tests. ${ }^{5}$

The exclusive criteria were as follows: the evidence of species other than $P$. falciparum, or mixed infections, pregnant women or breast feeding women, signs of heart, liver, or kidney problems, those consuming anti-malarial medicines in the last one month, and alcohol drinkers and drug abusers. $^{5}$

\section{RESULT AND DISCUSSION}

\section{General description of North Sulawesi (Indonesia)}

North Sulawesi Province is located in the North Celebes Archipelago between $0.30^{\circ}$ to $4.30^{\circ}$ North Latitude and $121^{\circ}$ to $127^{0}$ East Latitude. The climate is usually influenced by two seasons: dry and rainy. The dry season usually extends from April to September, while the rainy season goes from October to March.

The major health center in this region is the Prof. Dr. RD Kandou General Hospital which is also a teaching hospital (type B) since it collaborates with the Medical Faculty of Sam Ratulangi University.
As it enters the third millennium, North Sulawesi is actively developing its socio economic - culture programs by working in closer cooperation with neighboring countries called BIMP-EAGA (Brunei-IndonesiaMalaysia-Philippines). Besides that, there are some integrated programs; one of them is KAPET (Integrated Economic Development Zone) in North Sulawesi which incurporates Tondano - Bitung - Manado, Fishing Industries, Fish Canning Companies, and Gold Mining (with the Newmont Company). North Sulawesi also has many tourism areas, with focuses on art and culture. Every year people celebrate the Budaton Festival (a festival celebrating the coral garden reefs of the Bunaken National Marine Park); as well as the festival of Lake Tondano. Besides that, the provincial pride in religious unity can be seen at Bukit Kasih (Hill of Blessings) in the village of Kanonang. This attracts many domestic, national, and international tourists. These are the main reasons why North Sulawesi needs to be given priority in controlling the spread of malaria.

It has been reported that several outbreaks of malaria (unusual events) occured in North Sulawesi. In 1988 there were six outbreaks of malaria with 862 sufferers, and 13 deaths. Then in 1989 it was re-ported that there were nine outbreaks of malaria with 1136 sufferers and 10 deaths. The occurrence of these outbreaks was no doubt influenced by the heavy rains lasting throughout the whole year.

The resistance of $\mathrm{P}$. falciparum to chloroquine continues to increase rapidly ${ }^{5}$. Nowadays the new potent anti-malarial drug, artesdiaquine, is given to the sufferers who live in the areas where the outbreaks appear. ${ }^{2}$

\section{The identification of active cases}

There are four survey teams in this research, each consists of five people. Active case detection in several endemic areas was identified by examining the thick blood of the $P$. falciparum. Blood samples were taken from 10.00 till 20.00 AM. The 
total number of the subjects was 1481 , and the positive $P$. falciparum was 119 (8\%). The areas visited were 22 villages and four regions: Manado City, North Minahasa Region, South Minahasa Region, and Minahasa Region. The highest proportion of the positive blood tests was in Tombuluan villiage $(23.4 \%)$, followed by Tateli (15.6\%), Kokole I (15.4\%), Kombos (14\%), and Kokole II (13\%).

Tombuluan village including Pineleng and Minahasa Region, are located in a mountainous area. According to the local information, in those areas many people suffered from tropical malaria. They live far from the public heath center (located in Tateli Region). Tateli Region is in the District of Pineleng which is close to Manado City (Malalayang). Its road is traversed by the Trans-Sulawesi highway.
Kokole I and II villages belong to the district of Likupang, North Minahasa Region. These areas are endemic to tropical malaria.

Table 3 showed that the mean ages for both treated groups were the same. Based on sexes, there were 21 females and 14 males in the piper betle group. On the other hand in the chloroquine group there were 14 females and 21 males.

\section{Method of treatment}

The treated groups were given the mixture containing piper betle once daily in the morning after meals for three consecutive days, while the control groups were given chloroquine for three consecutive days according to WHO standards (4 - 4 - 2 tablets).

Table 2. Percentage of positive blood test ( $P$ falciparum) in several locations

\begin{tabular}{|c|c|c|c|c|c|}
\hline \multirow{2}{*}{ No } & \multicolumn{2}{|c|}{ Location } & \multirow{2}{*}{$\begin{array}{l}\text { Number of } \\
\text { blood test }\end{array}$} & \multirow{2}{*}{$\begin{array}{c}\text { Number of } \\
\text { positive blood }\end{array}$} & \multirow{2}{*}{$\%$} \\
\hline & Regency & (Villiage) & & & \\
\hline 1. & \multirow[t]{6}{*}{ Manado City } & Malalavang I \& II & 153 & 2 & 1.3 \\
\hline 2. & & Tikala Baru & 22 & 2 & 9.1 \\
\hline 3. & & Kombos & 56 & 8 & 14.3 \\
\hline 4. & & Buha & 64 & 2 & 3.1 \\
\hline 5. & & Taas & 28 & 2 & 7.1 \\
\hline 6. & & Pondol & 18 & 1 & 5.5 \\
\hline 7. & \multirow[t]{3}{*}{ Minahasa } & Tateli & 45 & 7 & 15.6 \\
\hline 8. & & Tombuluan & 64 & 15 & 23.4 \\
\hline 9. & & Lemoh & 55 & 0 & 0 \\
\hline 10. & \multirow[t]{12}{*}{ North Minahasa } & Talawaan & 66 & 0 & 0 \\
\hline 11. & & Likupang & 42 & 1 & 2.4 \\
\hline 12. & & Rinondoran & 51 & 0 & 0 \\
\hline 13. & & Kalinaun & 38 & 1 & 2.6 \\
\hline 14. & & Sarawet & 59 & 4 & 6.8 \\
\hline 15. & & Paslaten & 44 & 4 & 9.1 \\
\hline 16. & & Werot & 112 & 10 & 8.9 \\
\hline 17. & & Batu & 70 & 2 & 2.9 \\
\hline 18. & & Kaweruan & 35 & 1 & 2.9 \\
\hline 19. & & Kokoleh I & 228 & 35 & 15.4 \\
\hline 20. & & Kokoleh II & 54 & 7 & 13.0 \\
\hline 21. & & Lumpias & 87 & 9 & 10.3 \\
\hline 22. & South Minahasa & Tumpaan Baio & 90 & 6 & 6.7 \\
\hline & \multicolumn{2}{|c|}{ Total number } & 1481 & 119 & 8 \\
\hline
\end{tabular}


Table 3. The age distribution of groups treated with piper betle and chloroquine

\begin{tabular}{|c|c|c|c|c|c|}
\hline & \multicolumn{4}{|c|}{ Treatment } & \multirow{2}{*}{$\mathbf{P}$} \\
\hline & Chloroquin & $\%$ & Betle & $\%$ & \\
\hline \multicolumn{6}{|l|}{ Gender } \\
\hline Female & 14 & 40 & 21 & 60 & 0.239 \\
\hline Male & 21 & 60 & 14 & 40 & \\
\hline \multicolumn{6}{|l|}{ Age group } \\
\hline $10-19$ years & 9 & & 9 & & 1.000 \\
\hline $20-29$ years & 7 & & 7 & & \\
\hline $30-39$ years & 11 & & 11 & & \\
\hline $40-57$ years & 8 & & 8 & & \\
\hline
\end{tabular}

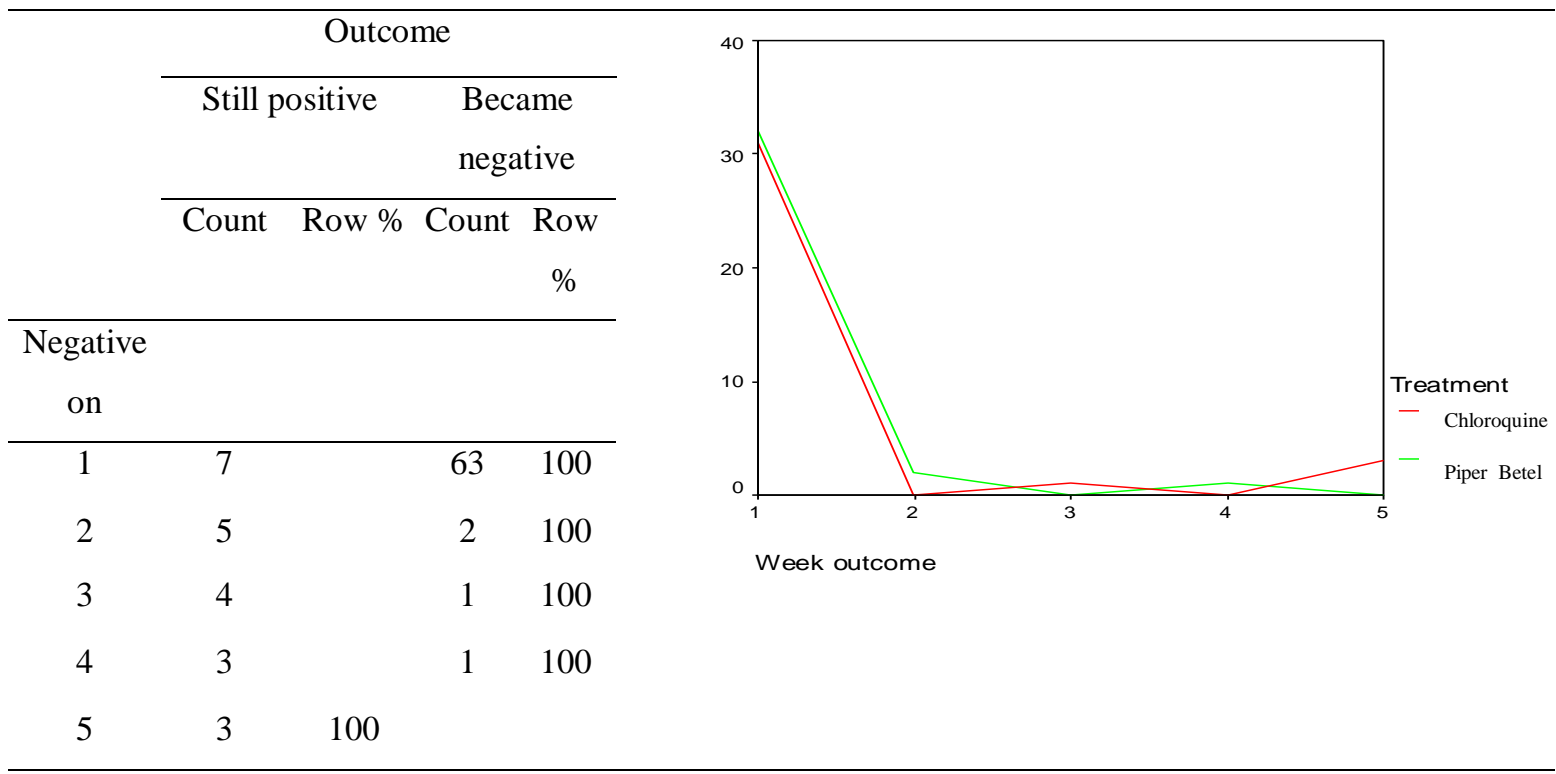

Figure 2. The number of malaria cases analyzed for testing the effectivity

The monitoring of the groups was done by those providing the medicine $($ Pengawas Minum Obat $=$ PMO $)$. Thick blood test was done at the day 12, 19, 26, and 33 of treatment. In the age range of 86 cases, the lowest age was 10 years and the highest was 88 years. They were divided into four age groups.

\section{The side effects}

After taking the extract containing piper betle one case felt discomfort in the pit of the stomach, and another case felt pain in the feet.

\section{The advantages}

The advantages of taking the extract containing piper betle were as follows: most cases felt better after taking that and could sleep well at night; one case recovered from one's backache directly; several cases who used to get headaches did not suffer from headaches anymore.

\section{The analysis of the effectiveness of the mixture containing Piper Betle}

The total data of this analysis were 70 cases which consisted of 35 cases treated with the mixture containing piper betle, and 35 cases with chloroquine as the control group. Table 2 shows the grouped samples, based on matching the ages. The average age of cases treated with the extract containing piper betle were the 
same with the control group treated with chloroquine.

Graphic on Figure 2 shown that the mixture containing piper betle is effective to remove the malaria parasites in the blood $(91.4 \%)$ at the end of first week. Chloroquine is still effective to remove the malaria parasites in the blood $(88.0 \%)$ and did not show malaria parasites at the end of the first week.

The previous research from Ridley (2002) reported that it was estimated about $80 \%$ of the worldwide parasite population was resistant to chloroquine. In addition, chloroquine has been used broadly in several Africa countries (Gbadoe, 1999: Goodman, 2004). ${ }^{12}$

\section{CONCLUSION}

Piper betle was as effective as chloroquine up to the end of the first week. All of the piper betle treated cases were negative by the end of the fourth week; whereas, the three subjects treated with chloroquine were still positive for malaria falciparum at the end of the fourth week.

In addition, further studies with increasing the number of samples to find out the effectiveness of the extract containing piper betle by using randomized clinical trial (RCT) design are still needed. These studies have to research the toxic effects of repeated usage of piper betle, too.

\section{AKNOWLEDGMENT}

The authors would like to thank the Health Offices in the North Sulawesi Province for giving the chance to conduct this research. Special thanks to Prof. Dr. Bastaman Basuki and Dr
Hudoyo Hupudio, MPH for their intelligent editing.

\section{REFERENCES}

1. Bruce-Chwatt IJ, Black RH, Clyde DF, Canfield CJ, Peters W, Wernsdorfer WH. Fundamental aspects. In: Chemotherapy of malaria. $2^{\text {nd }}$ Ed. WHO monograph, 1981/27:21-55.

2. Centers for Disease Control and Prevention Malaria. http://www.cdc.gov/malaria/ faq.htm, CDC, 2004.

3. Weber JL. A review: molecular biology of malaria parasites. Experimental Parasitology, 1988; 66: 143-70.

4. Do-PH, Cumes E, Prax, Emerging and reemerging infectious diseases - a challenge for public health. Schweiz-Rundsch-Med-Prax. 2000; 89(4): 125-32.

5. McIntosh HM, Olliaro P. Artemisinin derivatives, for treating uncompkicated Malaria (Cochrane Review). In: The Cochrane Library. 2004.1.

6. Tjitra E, Oemiyati S. Pengobatan malaria falsiparum tanpa komplikasi dengan halofantrin di daerah resisten klorokuin. Buletin Penelitian Kesehatan. 1992/ XX.

7. Laihad FJ, Gunawan S, Malaria di Indonesia. Editor: Hariyanto PN, Penerbit EGC, 2000; p. 18-25.

8. Darwis SN. Potensi sirih (Piper betle, Linn) sebagai tanaman obat. Warta Tumbuhan Obat Indonesia. 1992; 1(1): 9-11.

9. Thomas ANS. Tanaman obat tradisional. Jakarta: Kanisius, 1989: 65.

10. Andries L. Efektivitas antimalaria dan toksisitas akut pada tikus serta aktivitas mikrosomal hati tikus (perfusi hati). Proyek URGE dan Departemen Pendidikan Nasional (not published), 2000

11.Harrison's. Manual of medicine. 16 ed. New York: Mc Graw-Hill, 2005; p. 997-999.

12.Ginsburg H. Should chloroquine be laid to rest? ActaTropica. 27 July 2005: 16-23. 